\section{Call for plutonium shipment to be postponed}

Washington. Greenpeace International, the Washington-based Nuclear Control Institute and the Tokyo-based Citizens Nuclear Information Center, last month released a report supporting their protests against a forthcoming shipment of reprocessed nuclear waste from France to Japan.

The first commercial-scale shipment of plutonium extracted in France from spent fuel rods was returned to Japan in early of about 30 over the next 15 years to transport additional waste from fuel rods.

But the report, by Edwin S. Lynam, a physicist at Princeton University in New Jersey, argues that the shipment should be postponed until its safety has been more fully assessed. In particular, Lyman claims that current international safety standards for containing vitrified high-level waste may not be stringent enough. The tests of shipping casks on which these standards are based do not take sufficiently into account extreme conditions of fire, collision and immersion, he argues.

Lyman also claims that the radioactive leakage rates permitted by the Japanese government may also be too high. He says that the maximum radiation doses to which those close to casks might be radiation leaking from the casks. changes". the event of an emergency. 1993. The new shipment would be the first

exposed have been determined using limited data and rough estimates of cask leak rates, and the relation between radionuclide emission rates and the amount of

The report also claims that company literature gives a maximum permitted storage and transport temperature of 510 ${ }^{\circ} \mathrm{C}$. Lyman argues that this temperature could damage the casks and their rubber seals, and is close to the $600{ }^{\circ} \mathrm{C}$ threshold where the glass matrix around the waste could begin to undergo "undesirable

British Nuclear Fuels Limited (BNFL) - which owns 60 per cent of Pacific Nuclear Transport Limited, the company handling the shipment - says the report seems to be based on "dubious science". It also claims that the shipment would be carried out at $200-250^{\circ} \mathrm{C}$ and not $510^{\circ} \mathrm{C}$. The report, it says, "raises no new issues".

Speaking at a Washington press conference where the report was released, US congressmen and public-interest groups also criticized secrecy over the timing and route of the shipment's two-month voyage. This would make it difficult, they argued, to arrange contingency plans in

Julie Wakefield

\section{Indian scientists' missed opportunity}

New Delhi. Research by the historian $\mathbf{S}$. Ramamseshan, who is also editor of the Indian journal Current Science, has shown that disagreements among Indian scientists thwarted efforts by political leaders during the run-up to independence in 1947 to merge the three existing science academies into a "United Academy of Sciences of India", which would have provided the new government with a single source of advice on scientific issues.

Ramaseshan uncovered the information in the archives of the Indian Academy of Sciences (IAS) - which was founded in Bangalore in 1934 by his uncle C. V. Raman, who also won the Nobel prize for physics in 1930 . He had previously been denied access to the archives of the Indian National Science Academy in New Delhi on the grounds that it "would revive old controversies".

In particular, documents showed that the government proposed the idea of a single academy in January 1947, and again, just days before independence, in August the same year. But the inititiative failed, because each academy imposed "impractical" conditions.
Raman, who was president of the IAS until his death in 1970, was in favour of a single academy, but refused to agree to a transfer of IAS's property to the new body. This had been demanded by Shanti Swarup Bhatnagar, the president of the National Institute of Science which was later renamed the Indian National Science Academy - as one of the conditions for his institute taking part in the merger.

The National Academy of Sciences in Allahabad also refused to hand over its property, and insisted that a "quota" of places on the executive body and fellowships of the new academy be reserved for members of the old academy. This proposal was rejected by Bhatnagar, and the scheme was abandoned.

Rameseshan asserts that the proposal for a single national academy represented a lost opportunity for the Indian scientific community to have a single voice. As a result successive governments since independence have tended to take advice from individuals. This has amounted, he claims, to "showering patronage on a few and encouraging sycophancy".

\section{'Soft' privatization preferred for Natural Resources Institute}

London. The British government is to privatize one of its major research institutes, the Natural Resources Institute (NRI) in Chatham, Kent. The institute, which specializes in research on natural resource management in developing countries, is at present run by the Overseas Development Agency (ODA).

The move follows last year's government 'efficiency scrutiny' of public research laboratories, which was partly aimed at identifying institutions suitable for privatization. The report has been strongly criticized by science bodies and trade unions, and more recently by a House of Lords select committee (see Nature 372, 718; 1994).

Although the review failed to come up with many candidates for privatization, it recommended that public research institutes should be 'routinely' transferred to universities, in what some consider a milder form of privatization than the sale of institutes to private companies.

Indeed, a consortium made up of the University of Greenwich, the University of Edinburgh and Wye College (part of the University of London) jointly submitted to the ODA last year a proposal to take over NRI.

But NRI members of the Institution of Professionals, Specialists and Managers (IPMS) - the main trade union representing the 530 staff at NRI - have protested against any transfer of NRI, and have written an open letter to the minister for overseas development, and have started a petition.

Rob Black, chairman of the ODA branch of the IPMS and a plant pathologist at NRI, says the short-term perspectives of universities are not compatible with the aims of NRI.

Others are concerned that the consortium has a head start on other potential bidders who will not have enough time to prepare proper bids. A shortlist of two or three bids will be drawn up shortly after the call for tenders is made public. Those shortlisted will then submit detailed formal tenders by April. Maggie Verrall

\section{UK New Year honours}

John Maddox, Editor of Nature, has been awarded a knighthood in the Queen's annual new year honours list for services to science. A knighthood also goes to Arnold Wolfendale, professor of astronomy at the University of Durham, and due to retire as Astronomer Royal this year

César Milstein, deputy director of the Medical Research Council's Molecular Biology Laboratory in Cambridge is appointed a Companion of Honour. 